Relations industrielles

Industrial Relations

\title{
Intertemporal Compromise Revisited: A Reply
}

\section{James B. Dworkin}

Volume 33, numéro 2, 1978

URI : https://id.erudit.org/iderudit/028868ar

DOI : https://doi.org/10.7202/028868ar

Aller au sommaire du numéro

Éditeur(s)

Département des relations industrielles de l'Université Laval

ISSN

0034-379X (imprimé)

1703-8138 (numérique)

Découvrir la revue

Citer cet article

Dworkin, J. B. (1978). Intertemporal Compromise Revisited: A Reply. Relations industrielles / Industrial Relations, 33(2), 292-295.

https://doi.org/10.7202/028868ar

Tous droits réservés (C) Département des relations industrielles de l'Université Laval, 1978
Ce document est protégé par la loi sur le droit d'auteur. L'utilisation des services d'Érudit (y compris la reproduction) est assujettie à sa politique d'utilisation que vous pouvez consulter en ligne.

https://apropos.erudit.org/fr/usagers/politique-dutilisation/ 
for arbitration in both baseball and the University of Alberta cases. What does matter is whether the parties can expect a flip-flopping of awards and if this expectation is built into the negotiating strategy. If so, the likelihood that the parties will settle their differences without third-party intervention is reduced. None of Dworkin's evidence has refuted this proposition.

\title{
INTERTEMPORAL COMPROMISE REVISITED : A REPLY
}

\author{
JAMES B. DWORKIN
}

Originally proposed as an «ideal» substitute for interest arbitration of the conventional variety, final offer arbitration has recently been the target of much criticism in academic circles. ${ }^{1}$ Specifically, Professor Swimmer has postulated that final offer arbitration is subject to the «narcotic effect,» and more importantly, that arbitration awards will «flip-flop» over time as arbitrators attempt to avoid deciding for any party two time periods in a row. ${ }^{2}$ Rather than evaluating the comparative merits of the final positions of the parties in rendering their decisions, Swimmer argues that arbitrators will hand down decisions in time period $t$ based solely on what the award was in time period $\mathrm{t}$ - 1 . If true, this is clearly a serious indictment of the technique of final offer arbitration and of the neutrals who operate as Swimmer has suggested.

The evidence that I presented in this Journal ${ }^{3}$ from the realm of professional baseball demonstrated that a much closer, more rigorous examination of the intertemporal compromise notion was necessary before accepting it on face validity. Professor Swimmer has taken issue with my remarks on the grounds that: (a) professional baseball does not serve as an appropriate test group; and, (b) the results from pro-

* DWORKIN, James B., Assistant Professor of Management, Krannert Graduate School of Management, Purdue University.

1 For example, see Hoyt N. WHEELER, «Closed Offer: Alternative to Final Offer Selection," Industrial Relations, Vol. 16, No 3, October 1977, pp. 298-305; Clifford B. DONN, «Games Final Offer Arbitrators Might Play,»Industrial Relations, Vol. 16, $\mathrm{N}^{\circ}$ 3, October 1977, pp. 306-314; Peter FEUILLE, "Final Offer Arbitration and Negotiating Incentives," The Arbitration Journal, Vol. 32, N ${ }^{\circ} 3$, September 1977, pp. 203-220; and Paul C. SOMERS, "An Evaluation of Final-Offer Arbitration in Massachusetts," The Journal of Collective Negotiations in the Public Sector, Vol. 6, $\mathrm{N}^{\circ}$ 3, September 1977, pp. 193-227.

2 Gene SWIMMER, «Final Offer Arbitration and Intertemporal Compromise - The University of Alberta Experience», Relations Industrielles, Vol. 30, N 3, 1975, pp. 533-536.

3 James B. DWORKIN, "Final Position Arbitration and Intertemporal Compromise », Relations Industrielles, Vol. 32, N², 1977, pp. 250-261. 
fessional baseball support the intertemporal compromise hypothesis. In this reply, I would like to briefly discuss each of the points raised by Swimmer.

The first contention made by Swimmer is that «Arbitration of baseball salaries more resembles a grievance or rights arbitration of an individual than arbitration of outstanding issues in a collective agreement...» He argues this is so because of the relatively small average difference $(\$ 16,000)^{4}$ between the final offers of management and players, compared to the large differences in final positions in the Alberta case. Using Professor Swimmer's own estimates for the year 1973 , the $2.5 \%$ difference in the final positions of the parties in the Alberta case represents some $\$ 375,000$. When one examines the per capita difference involved, based on 1400 faculty members at the University of Alberta in 1973, ${ }^{5}$ the average difference between management and employee offers is only $\$ 267.85$. But more importantly, the final offer arbitration system used in professional baseball is clearly an example of interest arbitration at work. The arbitrator does not interpret existing contract language as would be the case in a rights dispute. The fact that only one player is involved per decision does not change the basic nature of the dispute resolution procedure! The neutrals involved in the professional baseball salary arbitration system are clearly resolving questions of what shall be the basic terms and conditions of employment. ${ }^{6}$

Swimmer's second criticism of baseball as a test group is that, "Clearly none of the baseball players involved are particularly concerned with the inflation rate...» He goes on to argue that an important part of his original scenario for intertemporal compromise was the role that inflation played in eroding worker's real wages and the real size of public employers' budgets. What Professor Swimmer has told us, in essence, is that rich people (the baseball players who used arbitration) don't care about inflation. But how does he know that (a) these players are rich, and/or (b) that they are not particularly concerned with inflation? I submit that a closer look at the situation demonstrates that there is neither logical nor empirical support for Swimmer's contentions. First, an average salary of around $\$ 35,000$ per year in professional baseball is not comparable to a similar salary in private industry or government. Sure, there are a few players who clearly are millionaires and would be classified as rich by Swimmer and others. But the average player is far from being a millionaire, and more importantly, his career is typically only 6 years long. After a player's

4 Swimmer's argument concerning the low financial stakes in professional baseball arbitration is even less appealing when one considers the spillover effects involved when any one player is able to command a higher salary than his similarly situated peers. Arbitrators are specifically instructed to consider comparable baseball salaries in rendering their awards.

5 The World of Learning, 1974-75. 25th ed., London, Europa Publications Ltd., 1974, Vol. 1, p. 248.

6 See Frank ELKOURI and Edna Asper ELKOURI, How Arbitration Works, 3rd edition, Washington, D. C., The Bureau of National Affairs Inc., 1973, p. 47. 
baseball days are over, who knows what salary or type of job he will have. Additionally, even if we make the assumption that all players are rich, this would not lead us to conclude that they are unconcerned with the inflation rate. The notion that rich people are unconcerned with inflation (compared to poor people) is one that must be either supported or refuted empirically. All Professor Swimmer has provided us with is his undocumented opinion. And finally, if baseball players are so rich and unconcerned about inflation, what would explain their interest in negotiating cost of living adjustment provisions in their collective bargaining contract with the baseball clubs ? ${ }^{7}$

Turning to the baseball results, Swimmer argues that, «... they are relatively consistent with the concept of intertemporal compromise... that the probability of arbitration in one year increases when arbitration has taken place the year before.» It seems clear that there is a higher probability of using final offer arbitration in year $t$, given arbitration has been used in year $t-1$, than there is of using arbitration for the first time in year t. However, one should be a bit cautious in interpreting this evidence as a clear indication of the narcotic effect of final offer arbitration. For one thing, the newness of the technique in baseball and the small sample size involved should cause us to be sceptical about placing much weight on trends developed over a twoyear period. Secondly, if one does want to speak in terms of trends, a much more important comparison would be to look at the number of new users of the technique over time. This decline (28 as opposed to 8) in initial use of final offer arbitration would seem to indicate that the technique is performing its theoretical role, inducing settlements at the bargaining table. Obviously, if a point is reached where the technique is no longer employed, there can be no intertemporal compromise. Finally, the players and clubs who used arbitration in 1974 certainly don't seem to be behaving as if they expected awards to flip-flop over time. Remembering that the baseball collective bargaining contract allows either side to demand arbitration, ${ }^{8}$ Swimmer's hypothesis would be that the losing players and the losing clubs in 1974 would expect to win at arbitration in 1975 (and thus reuse arbitration). The actual results were that only one losing player and none of the losing clubs from the previous year invoked arbitration in $1975 .{ }^{9}$ However, five winning players from 1974 did choose to use arbitration again in 1975 . Having been successful once, one might just as easily postulate that their reason for using arbitration again was the expectation of another win. If the narcotic effect is indeed important, perhaps it is

7 See, Basic Agreement Between The American League of Professional Baseball Clubs and The National League of Professional Baseball Clubs and Major League Baseball Players Association, Effective January 1, 1973, Article VI, B, (4) and VI, C, (4), pp. 10-11.

8 See Basic Agreement... op. cit. p. 6.

9 James B. DWORKIN, "The Impact of Final-Offer Interest Arbitration on Bargaining: The Case of Major League Baseball." Proceedings of the Twenty-Ninth Annual Winter Meeting of the Industrial Relations Research Association, 1976, pp. 161-169. 
because of expectations quite different from those suggested by Professor Swimmer.

Swimmer's last contention is that «It doesn't matter what an arbitrator's motives might be. ... what does matter is whether the parties can expect a flip-flopping of awards and if this expectation is built into the negotiating strategy.» It has already been noted that it is quite doubtful that the participants in the baseball salary arbitration system were operating under such a set of expectations. Moreover, the real crux of Swimmer's idea is that intertemporal compromise will occur because arbitrators seek to minimize the risk of alienating the parties. I have already noted that if this hypothesis can be empirically verified, that is, if Swimmer is right, he undoubtedly will be credited with having a valid criticism of the final offer arbitration technique. However, an alternative hypothesis is that in every instance, arbitrators make their decisions based upon the most reasonable final position placed before them. That is, it is quite possible that we may observe awards flip-flopping over time for reasons other than those suggested by Swimmer. The plain fact is that the mere observance of awards flip-flopping over time is not all that interesting. We need to know why the flip-flop occurred before we can make any statements about expectations of the parties and impacts upon negotiating strategies.

I agree with Professor Swimmer that none of my evidence has refuted the simple proposition that arbitration awards might flip-flop over time. However, should we be content to center our empirical investigation on this relatively minor point? I say absolutely not! What Professor Swimmer really has touched upon is a much more important phenomenon, that of how arbitrators make their decisions. This is the process that we need to subject to much further empirical scrutiny. My suggestion of an alternative way of explaining the existence of the flip-flop phenomenon was presented in the hope of stimulating empirical work in this area. To my surprise, Swimmer seems to be advocating that we forget about further empirical investigation into this important area and instead, just let the facts speak for themselves. However, it is only after we have resolved this issue of why intertemporal compromise occurs (if it in fact does occur) that we can really make any conclusive policy statements about the impact of final offer arbitration. 